\title{
Festas católicas brasileiras e os milagres do povo
}

Rita Amaral ${ }^{1}$

As festas religiosas, no Brasil, são incontáveis. Das tradicionais festas do cristianismo, como as da Natividade, ao constante homenagear católico de santos padroeiros, como Nossa Senhora Aparecida, Nossa Senhora da Conceição, dos Navegantes, de Nazaré, Santo Antônio, São Sebastião, São Pedro, São João entre muitos e muitos outros, o festejar não cessa. Além disso, outras religiosidades, como a indígena, por exemplo, além dos neoesoterismos, fazem do festejo sua forma ritual preferida. Não têm fim, do mesmo modo, as festas de candomblé e umbanda (Amaral, 2002), as festas judaicas, islâmicas e budistas. O fenômeno é antigo e surpreendente para aqueles não familiarizados com a cultura brasileira e seu permanente envolvimento com a linguagem das festas.

O catolicismo, contudo, é inigualável em sua potência festiva e o fenômeno é antigo. Thomas Ewbank, norte-americano protestante em visita ao

\footnotetext{
${ }^{1}$ Pós-doutorada em Antropologia pela Universidade de São Paulo, onde é pesquisadora do Núcleo de Antropologia Urbana; pesquisa religiões e estilos de vida urbanos. Além de vários artigos, publicou os livros Xirê!', o modo de crer e de viver do candomblé, pela Editora Pallas e Festa à Brasileira - sentidos do festejar no país que "não é sério", pela EbooksBrasil.com. Endereço para correspondência: ritaamaral@pobox.com
} 
Brasil no fim do século XIX, chocava-se com a dedicação extremada de tempo e recursos do brasileiro às festas para os santos, chegando mesmo a afirmar:

(...) o catolicismo, tal como existe no Brasil e, em geral, na América do Sul, representa uma barreira ao progresso, e outros obstáculos a ele comparados parecem pequenos. (...) incorporado como está nos hábitos e pensamentos do povo, que dele se acha impregnado até a medula dos ossos (...) gerações passarão antes que a venda caia de seus olhos, permitindo que se torne mentalmente livre" (Ewbank, 1976, p. 19, grifos meus).

Relativizando a origem protestante de Ewbank (sua visão racionalizada do tempo e do dinheiro) e as teorias evolucionistas da época, cumpre notar, contudo, que este pensamento ainda hoje pode ser encontrado no senso comum. É corrente a opinião de que um povo que realiza tantas festas é inconseqüente e esbanjador ou, pior, vive distanciado da realidade social e dos problemas que é preciso enfrentar, esperando a solução de centenas de santos diferentes e depositando seu destino em esferas sobrenaturais. Tal imagem dos brasileiros também é muito comum no exterior. Olhando, no entanto, para as festas, de um ponto de vista diferente do momento da festa, quando tudo é euforia e êxtase, alegria e entrega, é possível ver que a festa religiosa "à brasileira" não só não é alienante (no sentido de falta de consciência social, moral ou outra), como representou e representa, ainda hoje, importante papel na construção da sociedade e da sociabilidade brasileiras.

Nestas festas, além da experiência comunitária religiosa acontecem trocas culturais, sob suas diversas faces e sentidos. Fundem-se, associam-se, sobrepõem-se e são reinterpretados vários aspectos culturais dos grupos envolvidos, num verdadeiro ecumenismo cultural estabelecido pela arte, estética, música e pelas próprias crenças. A Festa de Iemanjá-Nossa Senhora dos Navegantes ou da Conceição, realizada em todo o Brasil por católicos, candomblecistas e umbandistas nos mesmos espaços e tempo é emblemática deste aspecto. Mas além dos aspectos propriamente religiosoculturais, a realização freqüente de festas faz parte de uma lógica de organização social e econômica que muitas vezes passa completamente despercebida. Essa lógica tem raízes no período colonial, quando a participação nas festas religiosas engendrou os modos de ação e de expressão favoritos dos brasileiros.

Desde a colonização do Brasil, as festas católicas serviram como um dos "modos de ação" do Estado português. As festas conquistavam os indígenas para a catequese e tornavam suportáveis aos portugueses e demais estrangeiros as agruras da experiência de enfrentamento da natureza desconhecida e selvagem, com gente, clima, plantas e animais estranhos. Foram elementos facilitadores do transplante do modelo social europeu para terras tropicais até quase os últimos tempos do período colonial, quando a Igreja Cató- 
lica imperava politicamente e as procissões e festas de santos eram praticamente intermináveis. Pode-se dizer que construção da sociabilidade brasileira foi marcada por festas e festividades de cunho religioso.

O constante festejar brasileiro não é recente, e a literatura dos viajantes nos prova isto. Chegando ao Brasil, muitos deles ficavam perplexos quando avistavam, por todo o percurso, imensas procissões, formadas por "alas" e carros alegóricos. Nestes, gente de todas as raças, fantasiada dos mais diversos personagens ricamente vestidos e adornados, membros de corporações de ofício e de irmandades religiosas, além de grupos de dançarinos e músicos, desfilavam, lado a lado. Nesta multidão, imensa quantidade de cruzes, pendões e estandartes eram agitados ao som de fogos de artifício. Notavam os viajantes que a cidade se preparava cuidadosa e caprichosamente para realizar com primor seus infinitos espetáculos de fé para que todos deles participassem extraindo a maior alegria possível, com devoção e entusiasmo quase extático. Neste período era obrigatória a participação, nas festas católicas, não apenas de todos os portugueses cristãos, como também dos índios e, posteriormente, dos escravos. Um dos mandamentos da lei da Igreja inclusive determina "Guardar domingos e festas de guarda". Tal preceito encontra seu sentido no mito de criação judaico-cristão, pois durante o $G \hat{e}$ nesis Javé ordena "Que haja luzeiros no firmamento do céu para separar o dia e a noite: que eles sirvam de sinais, tanto para as festas quanto para os dias e os anos" (Gênesis 1: 14-15). Os luzeiros sol e lua indicariam, deste modo, não só a passagem do tempo, mas, ainda, o tempo da festa, mediação entre passado e futuro, realizada no presente e através da qual a humanidade pode caminhar tanto para frente quanto para trás no tempo. Por todo o Antigo Testamento, inclusive, vê-se o próprio Javé preceituar a realização de festas, indicando datas, períodos, sacrifícios e toda a dieta do período festivo. Também no Novo Testamento há passagens significativas da valorização da festa nos momentos em que o próprio Cristo delas participa, deslocandose muitas vezes de locais distantes para freqüentá-las.

No Brasil colônia as festas se realizavam também em torno das "Entradas", recepções solenes dedicadas, desde a Idade Média, a soberanos, bispos e autoridades. Com a centralização dos Estados absolutistas como Portugal, elas serviram à cristalização de idéias absolutistas por meio da aclamação dos oficiantes mais próximos do poder. Os bispos visitadores da Santa Inquisição, os governadores-gerais e vice-reis recebiam igualmente tais homenagens. Eram celebradas festas pela Igreja em datas importantes na vida dos governantes portugueses (casamento, nascimento e morte) implicando, portanto, o reconhecimento do poder real e da burocracia que o representava na Colônia. A parceria entre Igreja e Estado tornava as festas simultanea- 
mente sagradas e profanas. As festas acentuavam a identificação entre Igreja e Estado.

O rei e a religião, numa aliança colonizadora, estendiam o seu manto protetor e repressor sobre as comunidades, manto este que apenas por ocasião de festividades coloria-se com exuberância. (Del Priore, 1994, p. 15)

O período que vai dos séculos XVI a XVIII, que concebeu um conjunto de instrumentos articulados para preservar o sistema absolutista, teve nas festas um dos elementos mais notáveis e persuasivos. Segundo José Antônio Maraval (apud Del Priore, 1994, p. 15), a festa barroca como prática de poder não só deixava o cotidiano em suspenso como tornava mais suportável o trabalho e as penalidades impostas aos que se submetiam ao Estado metropolitano. Espelho das formas modernas de governo, a festa era um meio de instituição política e manifestação do poder crescente do Estado português. Era, também, um meio de diminuir as tensões inerentes à diversidade étnica e às distinções sociais da Colônia. Entretanto, constituía-se e consolidava-se a partir das diferenças culturais, da participação conjunta de múltiplos atores anônimos, de seus ritmos e danças e do riso crítico e jocoso da cultura dos diferentes grupos no interior dessa mesma festa. A índios, portugueses, negros, ciganos, espanhóis, franceses, enfim: a todos, era obrigatório participar das festas, como mostra Maria Odila Dias (1984) em seu estudo histórico sobre cotidiano e poder no período colonial a respeito das padeiras, em São Paulo, ameaçadas de prisão e confisco de suas licenças caso se recusassem, como vinham fazendo a título de protesto, a participar das festas. Carpinteiros, oficiais de cutelaria, padeiros, alfaiates, ourives, todos deviam desfilar nas festivas procissões. Em meados do século XVIII, em Recife, por exemplo, era possível ver uma irmandade de mulatos e libertos organizar procissões em que se mesclavam aspectos religiosos e profanos com diferentes intenções e sentidos. Na descrição de uma procissão de 1745 observa-se inclusive que mesmo antes da abolição da escravidão os negros libertos e mulatos não apenas eram capazes de acumular riquezas como também de apresentá-las nas festas do mesmo modo que faziam os colonos brancos. E nota-se, ainda, a presença de imagens incorporadas do imaginário erudito ("pecados capitais", "virtudes" e "continentes") que desfilavam nas procissões como alegorias e fantasias. O intercâmbio entre as culturas aparece claramente nas festas da época, assim como suas mútuas percepções (Del Priore, 1994, p. 49-50). Na verdade, é muito difícil, neste período, dividir as festas em religiosas e profanas, porque uma está na outra. As comemorações do Natal são outro exemplo. Autos natalinos em forma de bailes pastoris para louvar e cantar o nascimento de Jesus eram seguidos de cocos, fandangos e batucadas, encerrados por danças denominadas "chacotas". Nos bailes pastoris, apesar da presença de São José e Nossa Senho$\mathrm{ra}$, os reis magos e pastores saudavam o Divino Menino com temas e títulos 
profanos como "Baile da Aguardente", "Baile da Patuscada", "Baile do Caçador" etc., usando, em geral, linguagem grosseiramente popular (Azevedo, 1959; Cascudo, 1969; Amaral, 1976, Brandão, T., 1976 e outros). Estes temas eram cantados em adros e portas de igrejas, e depois levados em cortejos de dançarinos e músicos à vizinhança e à praça pública. Mello Moraes Filho (1979) diz que a música sacra das festas religiosas mesclavase geralmente com ritmos populares portugueses e espanhóis, mostrando que as fronteiras entre sacro e profano, popular e erudito, não estavam claramente estabelecidas. Desse modo, aos poucos, foi vicejando um poderoso sincretismo das práticas étnicas, que começaram a se fundir no período colonial. Del Priore acrescenta:

As festas (...) misturavam também os corpos. Embora a maioria dos narradores destaque a presença de 'nobres de armas, chefes militares, embaixadores, arcebispos, bispos, prelados, com capas velhas e carmesins (...) damas e dueñas' tradicionais suportes do Estado absolutista, são também unânimes em destacar a presença do povo. (1994, p. 18)

A presença das danças profanas nas festas religiosas surge como resquício da catequese jesuítica. A Igreja permitia que índios e negros dançassem, pois a dança era considerada uma maneira de agradar a Deus (Davi dançou para Javé). Depois do Concílio de Trento (1545-1563), as danças se tornaram elementos enriquecedores e atraentes acrescidos ao culto católico. $\mathrm{O}$ poder da festa e da dança era tão real que mesmo as danças e músicas dos escravos, consideradas inferiores e não civilizadas, eram permitidas nos dias festivos, ${ }^{2}$ o que acabou facilitando a permanência da religiosidade africana no Brasil, uma vez que esta se liga intimamente às festas para a incorporação de seus deuses no transe (Amaral, 2002). A festa colonial possibilitou, desse modo, o espaço necessário à construção de estratégias contra a repressão do catolicismo inquisitorial, ao mesmo tempo em que permitiu a absorção de alguns de seus valores.

A propagação das procissões em dias de festa religiosa tinha função tranqüilizante e protetora. Itinerários importantes para a comunidade, cantos e ladainhas somavam-se nas freqüentes procissões para atender a necessidades "imperiosas", como a saúde do rei, falta de chuva, epidemias etc. Ao lidar com a demanda por religião e fé por parte dos colonos, que viam nas procissões um apoio espiritual, a Igreja passou a lhes dar justificativas históricas e teológicas. Mas aproveitou também para disciplinar e controlar a população. Isto porque as procissões eram e são, ao mesmo tempo, eventos comunitários e hierárquicos. Elas exprimem a solidariedade de grupos su-

\footnotetext{
${ }^{2}$ Na Bíblia, o próprio Deus ordena: "E na tua festa te regozijarás, tu, teu filho e tua filha, teu servo e tua serva, e o levita, o peregrino, o órfão e a viúva que estão dentro das tuas portas." (Deuteronômio 16:14). Portanto, todos os que estivessem próximos a uma família deveriam participar da festa, sem exceções.
} 
bordinados a uma paróquia, reforçando tanto os laços de obediência à Igreja quanto os dos membros de uma comunidade (Alves, 1971; Alves, 1980; Berger, 1985; Brandão, 1989; Ewbank, 1976; Rugendas, 1972; Zaluar, 1983 e outros). A importância das festas religiosas era tanta que, depois do Concílio de Trento, confirmando o investimento catequético e pastoral que as norteava, surgiram publicações especializadas para orientar o clero na sua organização e realização.

Normalmente estas festas ocorriam, como ainda ocorrem, com a participação das economias particulares. Na época, como o catolicismo era a religião do Estado, era difícil recusar contribuição. Todas as instâncias da comunidade eram envolvidas na elaboração das festas, incluindo os funcionários do governo português, pois cabia a eles aprovar sua realização e, quando não houvesse patrocínio particular, financiá-las. Thomas Ewbank (1976) anota em seu diário de viagem as inúmeras vezes em que os agentes da Igreja ou do Estado corriam de porta em porta, quase diariamente, recolhendo doações para a realização das infindáveis festas de santos, os pedidos de doações em jornais e as infinitas esmolas que se davam nas igrejas para que as festas fossem realizadas com pompa. Suas descrições deixam claro os custos e o trabalho envolvidos nas inúmeras festas: "a festa de [São] Francisco de Paula foi celebrada com muito brilho. Iluminada por mais de mil tochas e ornamentada de novos tapetes de seda de damasco, a casa [igreja] do Santo estava concorrida" (Ewbank, 1976, p. 164). Para a festa do Espírito Santo, diz o autor (1976, p. 191) que as igrejas da Lapa, Santa Rita e Santa Ana, no Rio de Janeiro, enviavam esmoleiros durante cinco semanas seguidas às ruas da cidade inteira; que visitavam até mesmo os navios da baía gritando e pedindo "esmolas para o Espírito Santo".

A solidariedade inspirada pela participação na festa proporcionava a oportunidade de as diversas ordens exibirem publicamente seus recursos. Após o Concílio de Trento, quando os leigos conquistaram aos poucos maior espaço no interior das irmandades religiosas, a procissão passou a representar a própria religião, a própria igreja em marcha, rumo ao destino de glórias do paraíso, mas como resultado de uma competição de recursos e de superioridade econômica ou social de seus membros (Abreu, 1988; Reis, 1991; Del Priore, 1994). A vontade de participar, vestida de colaboração e de boas intenções peculiares do momento da festa, contaminava as classes mais ricas, incentivando-as a uma participação supostamente "filantrópica". A festa contagiava a todos de tal forma que até os moradores quase indigentes se viam forçados a contribuir, especialmente por causa da coerção da Igreja (Ewbank, 1976, Dias, 1984, Del Priore, 1994). A festa arrastava os diferentes segmentos sociais, intimando-os, mais do que os convidando, a participar dela. A preocupação com o espetacular e o fausto nas vibrações 
religiosas aparecia claramente nos concílios e sínodos realizados depois do século XVI, com o objetivo de atrair multidões de conversos.

O povo era, portanto, "convidado", embora fosse também quem arcasse com a maior parte das despesas. O calendário de festas coloniais procurava moldar a vida e os interesses das populações à aliança entre Igreja e Estado, interferindo nas formas de sociabilidade e de economia dos colonos. Contudo, ao mesmo tempo em que era imposta, a festa criava, ou não conseguia evitar, brechas que ensejavam o aprendizado da organização, da cotização, da colaboração, da transformação, resistência e dramatizações públicas de ideais e utopias dos grupos mais diversos. Tudo era feito para atrair a população para a festa, pois a participação do povo a partir da decisão oficial de realizá-la era imprescindível, já que a importância e o poder da Igreja e do Estado só poderiam se expressar no número de pessoas que pudessem cooptar. Por isso mesmo, tanto Estado como Igreja se garantiam através da participação "forçada" (Dias, 1984; Del Priore, 1994). Este procedimento, entretanto, ao delegar à iniciativa popular a realização de vários preparativos, ia aos poucos abrindo brechas de extravasamento no interior de uma sociedade pautada pela exploração e pelo trabalho escravo, pondo em contato diferentes grupos, igualmente dominados, que, paulatinamente, passam a introduzir sua festa dentro da festa oficial e a se apropriar dela, transformando-a, vivendo nela sua própria utopia, seus valores, gestando a cultura popular brasileira.

Acontecendo nas ruas, no contexto de exaltação e alegria de gente de todo tipo reunida, as festas começam a ganhar, aos poucos, alguma independência da festa oficial. Danças, fantasias, personagens dos desfiles e carros alegóricos, ritmos e harmonias profanas invadiam lentamente o quadro da comemoração original e, embora estivessem articuladas com o todo a que deviam se amoldar, cada uma dessas manifestações tinham vida própria e significado peculiar. $\mathrm{O}$ agradecimento por milagres recebidos foi uma das primeiras inserções feitas pelo povo na festa. Sendo o milagre a introdução de uma nova ordem dentro da ordem esperada anteriormente, sua ocorrência na festa acrescenta nova mediação entre sagrado e profano, entre ordem divina e vontade humana, entre o pedido humano e a aquiescência divina. A força simbólica do milagre na festa é tão verdadeira e arraigada na cultura popular que ainda é comum que as festas sejam promovidas e financiadas por pagadores de promessas, como acontece na Festa do Divino (Brandão, 1973), no Círio de Nazaré (Alves, 1980) e no Tambor de Crioula (Ferretti, 1995). Não foram inseridos apenas milagres e categorias de representação religiosa nas festas de santos. Inserções profanas também foram feitas aos poucos. O povo fez ainda outra importante inserção na festa e que congregava a população de maneira unânime: a distribuição de comida. As festas e 
procissões, na Colônia, permitiam não só o divertimento, a fantasia e o lazer do povo, mas também o estabelecimento de vários sentidos para o papel aparentemente irrelevante da festa. A distribuição de comida e bebida, por exemplo, e a espetacularização das doações recebidas podem ser entendidos como concentração e redistribuição de bens, o que também acontecia (através do critério da participação dos mais diversos grupos sociais) com os bens simbólicos, permitindo a inclusão, na cultura da festa brasileira, de diversas visões e representações de mundo.

A festa colonial constituía um desafio de organização para os diversos grupos sociais contra as dificuldades do cotidiano, além de uma evasão das tensões acumuladas contra o poder, fosse ele concentrado na figura do senhor de escravos, na do funcionário metropolitano do governo português ou na da igreja católica. Mas ela se constituía, também, como espaço privilegiado para a criação de tradições e consolidação de costumes, permitindo que as culturas estabelecessem contato e, com isso, compartilhassem símbolos, valores lúdicos, religiosos e artísticos.

A igreja católica e os monarcas modernos perceberam a paulatina apropriação popular das festas como desordem e excesso. Contudo, em vez de proibi-las, procuraram integrá-las e usá-las em proveito da ortodoxia e da obediência. Para as camadas mais pobres da população colonial, por sua vez, as festas pareciam ser um espaço de reordenação ritualizada, território cheio de símbolos que anunciavam a insatisfação social. Insatisfação que se mostrava não apenas na violência física, como na "obscenidade" dos movimentos corporais não dominados dos negros, na detração da autoridade e no riso. Este processo de lenta apropriação popular do espaço social da festa atinge o auge no século XX, quando a festa se transforma em patrimônio e modo de ação dos grupos populares. Festa de índios, de negros ou portugueses, ela é indissociável da cultura brasileira.

A histórica participação popular na festa parece contrastar com a baixa participação política do povo brasileiro na história do país. Contudo, é possível ver que ela tem representado importante papel na construção de identidades e na organização política e econômica dos grupos sociais, sendo a linguagem por excelência da cultura brasileira. Ela é uma das dimensões nas quais se dão, para vários grupos, algumas das primeiras experiências do sentir-se cristão e brasileiro. A organização primária, formada para realizar a festa, muitas vezes ultrapassa os próprios limites e expectativas originais de sua produção, estendendo-se por outros campos de ação, especialmente nas grandes metrópoles, onde a experiência do agrupamento e da associação pode construir laços afetivos, relações diretas e personificadas e reforçar a capacidade de ação. 
Para entender como, nas festas, constroem-se e destroem-se relações politicamente significantes, é preciso conceber a política em termos mais amplos: como uma relação de forças, sem mediação obrigatória de instituições e aparelhos ligados ao Estado. Através do jogo de forças são criadas novas identidades e forjados novos conteúdos para a noção de direito, alargando continuamente sua abrangência. As creches e escolas surgidas a partir da realização de festas são um exemplo disso.

\section{Festas juninas}

Dois exemplos deste potencial da festa no Brasil são os ciclos das chamadas "festas juninas" e o das festas dos santos italianos. As festas de Santo Antônio, São João e São Pedro, realizadas em todo o país, são exemplares do quanto a festa dos santos se tornou um empreendimento que abrange ação política, publicidade e comércio controlado em grande parte pelas populações locais. O exemplo da festa de Nossa Senhora Achiropita, por sua vez, demonstra como a festa religiosa pode ser incorporada como um modo de ação comunitária. Vejamos primeiro as festas juninas.

No Nordeste brasileiro, a perspectiva das festas juninas transforma as cidades e o espírito das pessoas. Muitos nordestinos fora de seus estados de origem costumam voltar para a cidade natal durante as festas juninas. No Sudeste, é comum nordestinos abandonarem o emprego, faltarem por uma quinzena de dias ou trocarem o período do Natal por alguns dias de folga em junho ou, ainda, negociarem suas férias para gozá-las no meio do ano e participar das festas juninas de sua terra. O mês de junho é um período de refluxo migratório, fato que as companhias de transporte rodoviário e aéreo atestam. Os que não conseguem voltar para suas cidades ainda podem encontrar alternativas nas festas juninas realizadas nos grandes centros urbanos sob iniciativa das Secretarias de Cultura.

A vinda de muitos nordestinos para o Sudeste e o crescimento da visibilidade da festa junina na mídia, que a descobriu como espetáculo, implicou uma expansão vertiginosa da festa de São João no Nordeste e no Sudeste. Isso vem ocorrendo não apenas em Centros de Tradição, como o CTN de São Paulo (Centro de Tradições Nordestinas) ou CTG (Centro de Tradições Gaúchas) e bairros de periferia, mas, no caso de São Paulo, também mediante a iniciativa dos governos estadual e municipal, que incorporaram os eventos juninos à programação cultural oficial. Na capital paulista, a Secretaria Municipal de Cultura promove há alguns anos, no Vale do Anhangabaú, uma festa junina que conta com a presença de duplas sertanejas, como Chitãozinho e Xororó, e artistas "regionais", como Sivuca, Renato Borguetti, Quinteto Violado entre outros. A festa começa numa sexta-feira (inde- 
pendentemente da data ser ou não dia de algum santo, pois o critério levado em conta é o fim da semana de trabalho e a viabilidade de ficar acordado até tarde em função da festa) às $19 \mathrm{~h}$ (para que aqueles que saem do trabalho às 18h também possam assisti-la), com a celebração da Missa do Vaqueiro tradicional em Pernambuco, que revive a história de um vaqueiro assassinado pelo adversário. Iluminada por milhares de velas acesas no Anhangabaú, a missa termina com um show pirotécnico que dura cerca de 8 minutos e com a apresentação de músicos de forró. As pessoas dançam no Vale, a maioria nordestinos que vivem em São Paulo. Segundo a Secretaria Municipal de Cultura, comparecem à festa cerca de 35 mil pessoas por dia, cuja segurança fica a cargo de 200 guardas civis metropolitanos.

De acordo com informações de jornais, TVs e rádios de todo o Brasil, a festa de São João esvazia o plenário do Congresso Nacional, em Brasília. Para se ter idéia da importância do São João nordestino, basta observar que em 1993 promessas de cargos e de não cortar algumas emendas de deputados durante a reprogramação orçamentária não foram suficientes para ajudar a aprovar o IPMF. O governo só conseguiu a participação geral no plenário no dia 22 de junho de 1993 ao prometer aos deputados nordestinos que eles teriam reservas nos aviões para retornarem a seus estados antes das festas de São João, no dia 23 de junho à noite. A então deputada Roseana Sarney (PFL-MA) declarou:

As pessoas do Sul do país podem não acreditar, mas as festas de São João são tão importantes para o político nordestino que poderiam impedir a votação do IPMF. (Folha de $S$. Paulo, 21/06/1993)

José Carlos Aleluia (PFL-BA) era um dos casos dos muitos deputados que se jogam de cabeça nas festas de São João:

Viajo nesta quarta feira pela manhã para a Bahia, passo o São João no carro, visito os arraiais e quadrilhas em cerca de dez municípios distribuídos por cerca de $2.000 \mathrm{~km}$ do interior (...) se eu não for, não me reelejo. (Folha de S. Paulo, 21/06/1993)

Para o deputado, a festa junina é importantíssima. A seu ver, ficar distante do que há de mais popular na Bahia constitui um suicídio político, já que o distanciamento entre a política oficial (a do Estado) e a política "paralela" (local e da festa) significa a não reeleição. Seu discurso sugere que seus eleitores não se importam tanto se sua ausência no plenário nesse período. Pois, seu lugar, em junho, é na festa de São João, levando prestígio e patrocínio ao evento por eles organizado, mais que no plenário do Congresso. A política da festa local adquire, assim, maior relevância que o interesse nacional.

Com a descoberta das festas como produto turístico e econômico, propiciada sobretudo com os carnavais carioca, baiano e pernambucano, as gran- 
des festas populares brasileiras ganharam maior espaço na mídia, com isso, recursos do Estado para sua implementação como evento oficial. O crescimento das festas juninas de Caruaru e Campina Grande é significativo das transformações pelas quais a festa tradicional, religiosa, vem passando sem necessariamente abandonar suas características de mediação entre tradição e modernidade, urbano e rural.

Talvez o melhor exemplo da expansão e relevância que a festa o São João vem adquirindo na região Nordeste seja representado pela festa de Caruaru, Pernambuco, que compete pelo título de "Melhor São João do Mundo" com Campina Grande, Paraíba. Caruaru possui, hoje, o mais conhecido São João do Brasil, embora se diga que em grandeza se equipara ao de Campina Grande. Os caruaruenses não concordam com isso, evidentemente:

Campina Grande é uma cidade ridícula, a maior parte das ruas não é nem sequer calcimentadas [pavimentada]. Porém é uma cidade industrial e com isso o dinheiro lá entra mais fácil que em Caruaru que é comercial. Mas Caruaru tem mais estrutura para festa. (Éder, 29 anos, habitante de Caruaru)

Localizada às margens da BR 232 e distante 132 quilômetros da capital pernambucana, Caruaru é conhecida por sua feira de artesanato e, atualmente, pela festa de São João. Com pouco mais de 250 mil habitantes, clima ameno e população tida como acolhedora, é a cidade líder na região e um dos mais importantes centros de atividade econômica e cultural do interior nordestino. Em junho, noite ou dia, os acordes das sanfonas, do triângulos e das zabumbas arrastam milhares de pessoas de todo o país ao longo das ruas, nas palhoças, palhoções e pelo pátio de eventos. São mais de duzentas ruas ornamentadas com bandeirinhas e balões para o forró e o passeio das quadrilhas. Durante todo o mês de junho Caruaru se torna um gigantesco arraial. Uma cidade cenográfica foi criada visando trazer para o centro de Caruaru o "clima da roça" e receber os turistas que chegam nos lotados "trens do forró". Uma das maiores atrações da festa, o trem do forró parte de Recife e percorre diversas cidades incorporando novas pessoas à festa, muitas delas devotas de Santo Antônio, outras, turistas em busca de divertimento. No Trem, o forró não pára de ser tocado, dançado e cantado. Todos os vagões são animados por bandas. A partir da entrada do município, no distrito de Gonçalves Ferreira, até a parada final, forma-se um verdadeiro cordão humano de pessoas acenando para os passageiros. Às tardes de sábado e domingo, centenas de pessoas esperam pelos turistas do Trem na estação da RFFSA em Caruaru. A cada viagem, mais de 600 turistas chegam à cidade. São dez Trens do Forró ao todo, somando seis mil pessoas que chegam a Caruaru apenas por via ferroviária. Após o desembarque, dança-se forró no Pátio de Eventos Luiz Gonzaga, uma grande área para shows, e na Vila do Forró, a cidade cenográfica. A área dos shows possui 
um enorme palco de $800 \mathrm{~m}^{2}$, que possibilita ao público assistir às atrações musicais de qualquer ponto do Pátio de Eventos. Durante os eventos, um locutor explica, em inglês, francês e português, os acontecimentos da festa, orientando os turistas. Na Vila do Forró tenta-se reproduzir, para que os visitantes conheçam e experimentem o clima e a cultura material de uma "verdadeira cidade do interior" em tempo de festa. A Vila é uma réplica de um arruado, com casas simples e coloridas, posto bancário e de correio, delegacia, subprefeitura, mercearia, igrejinha, forrós pé-de-serra, restaurantes. Entre as casas, há a casa da rainha do milho, da rezadeira, da parteira, da rendeira, de apresentação de mamulengos e outras personagens do interior. São $1.500 \mathrm{~m}^{2}$ de área cenográfica construída para oferecer, durante o ano todo, um pouco do São João de Caruaru aos turistas, embora a festa só ocorra em junho. Para a construção da Vila do Forró, foram pesquisados nos povoados da zona rural da região os traços arquitetônicos e as cores utilizadas pelos pedreiros, "sem orientação acadêmica" segundo os organizadores. Algumas casas da Vila, por esta razão, não possuem reboco. A Vila do Forró tem, inclusive, "habitantes". Atores encenam, de forma bem humorada, o cotidiano de personagens típicos da região, como o padre, as beatas, a parteira, o soldado de polícia, o poeta, o prefeito e a primeira-dama. O Coronel Ludugero e sua amada Filomena são personagens de destaque, que passeiam pela Vila do Forró e pelo Pátio de Eventos como se fossem reais. Os turistas participam, desse modo, de uma encenação teatral interativa na "Capital do Forró".

Outra atração muito popular do São João de Caruaru é a "Caminhada do Forró", que sai do Pátio de Eventos. Verdadeira procissão dançante - lembrando descrições dos viajantes coloniais - cujo trajeto tem como destino a capela do Alto do Moura. Ali, ao final da caminhada de quinze quilômetros, é degustado o "Maior Cuscuz do Mundo", oferecido gratuitamente aos brincantes. O cuscuz, prato típico do Nordeste, é servido com leite de cabra e guisado de bode. Depois de servido o cuscuz, dança-se forró pé-de-serra na palhoça permanente do Alto do Moura. O "Maior Cuscuz do Mundo" é cozido em uma cuscuzeira gigante, medindo 3,3 metros de altura e 1,5 metro de diâmetro, com capacidade para 700 quilos de massa. O cuscuz consome 300 quilos de massa de flocos de milho, 20 quilos de farinha de mandioca, 5 quilos de sal e 10 quilos de margarina. A edição de 1997 do Guiness Book cita o "Maior Cuscuz do Mundo": recorde que alcançou 600 quilos em 1995.

Toda essa movimentação aquece o comércio de produtos locais e promove a auto-estima local. A chegada de turistas aumenta o público para os espetáculos e enriquece as oportunidades de troca e relacionamento. O que a prefeitura arrecada com a festa é reinvestido em infraestrutura para a cidade. 


\section{Festas de santos italianos em São Paulo}

Na capital paulista, o equivalente dos festejos juninos é o ciclo de festas promovido pela comunidade de descendentes de italianos aos santos Nossa Senhora Achiropita, San Genaro, São Vito Mártir, Santo Emídio e Nossa Senhora de Casaluce. São festas que prestam homenagem aos santos, mas, também, festas étnicas que revigoram as tradições italianas. As colônias napolitana, calabresa e cirignolana, tradicionalmente rivais, enfrentam-se nestas festas, disputando quem oferece a melhor homenagem aos santos padroeiros. As comunidades envolvidas nelas, compostas majoritariamente de imigrantes e descendentes destes, ${ }^{3}$ de classe média alta ou baixa, zelam com disciplina pelos costumes herdados de pais e avós, muitos deles fundados na religião e, segundo alguns participantes, ainda em vigor nas regiões de origem.

A Associação São Vito Mártir realiza anualmente, há 75 anos, a festa de São Vito no bairro "italiano" do Brás, com duração de sete semanas a partir do começo de junho. Além de festejar São Vito, a festa visa arrecadar fundos para a manutenção de uma escola e uma creche da associação. O mesmo acontece com a Festa de Santo Emídio, em Vila Prudente, que homenageia o santo há 53 anos, no mês de agosto. Além da procissão, as massas são a principal atração da festa: canelones, pizzas, lasanha, rondelli. São toneladas de massas "oferecidas" na comemoração.

Cerca de quinhentos casais da comunidade se reúnem para arrecadar dinheiro através de outras festas, doações dos comerciantes, bingos, rifas e do auxílio de instituições públicas, como a Administração Regional do bairro e a Eletropaulo. Obtidos os recursos ${ }^{4}$ para a compra dos ingredientes das massas, molhos etc., a comunidade dedica-se à execução dos pratos, que são vendidos nas ruas dos bairros, em barracas ou galpões, prontos ou crus, com acompanhamentos diversos. Além das massas, há espetáculos musicais de artistas da própria comunidade e shows, aos domingos, de uma orquestra. $\mathrm{O}$ lucro auferido nestas festas gira em torno de $20 \%$ do dinheiro investido em sua organização. É um lucro alto, considerando-se que o gasto na festa é coletivo, o que tornam diminutas as contribuições individuais que, somadas aos patrocínios e ao apoio do Estado, compõem o total do investimento. $\mathrm{O}$ montante arrecadado em 53 anos da festa de Santo Emídio já permitiu a construção de creches, de asilos para idosos e da própria igreja matriz do

\footnotetext{
${ }^{3}$ Apesar do cardápio e do ethos da festa, as comunidades não são formadas apenas por italianos. Segundo uma das responsáveis pela festa de Santo Emídio, da Vila Prudente, o bairro é um "cadinho" de miscigenação de imigrantes. "Aqui temos descendentes das mais diversas regiões do mundo: espanhóis, japoneses e, é claro, italianos", comenta.

${ }^{4}$ Uma das participantes revelou que, em 1993, a festa custou trezentos e vinte mil dólares.
} 
bairro. A verba arrecadada com a festa de 1993 destinou-se à construção de quatro salas de aula para crianças carentes da região.

As festas mencionadas seguem o modelo (não apenas em termos da festa, mas também da organização e realização) desenvolvido originalmente pelos moradores do bairro do Bexiga na comemoração de Nossa Senhora Achiropita, cuja festa, estudada por Maria Coimbra (1987), é uma das mais populares e tradicionais da capital paulista. São ao todo dez noites de festa italiana, sempre aos sábados e domingos, do início de agosto ao começo de setembro.

Para a festa são instaladas, na rua 13 de Maio, no quarteirão da igreja, quinze barracas que funcionam das 18 às 24 horas, oferecendo pratos italianos típicos, como pastas, fogaças e pizzas, além de bebidas, doces, espetos de churrasco. São gerenciadas por pessoas do bairro, que prestam contas à Associação de fiéis da santa, no final da noite. Na "Cantina Madonna Achiropita", além de farta mesa com pratos frios e quentes preparados pelas mammas da comunidade, há música italiana típica ao vivo, danças, leilões e sorteio de brindes. A partir das terças-feiras, as mammas trabalham em tempo integral na preparação de fogaça, fricazza, polenta, antepastos, melanzana al forno, sfogliatelli e canolli, entre outros pratos. A Cantina cobra mais caro do que as barracas de rua, mas sua comida é melhor.

Para atender às mais de 100 mil pessoas que comparecem à festa, são gastos cinco toneladas de farinha de trigo, três toneladas de espaguete, 2500 latas de óleo, 3500 quilos de muzzarela, dez mil litros de vinho a granel, 15 mil litros de chope e 15 mil litros de refrigerantes. Antártica, Etti, Adria e J. Macedo colaboram com a festa, doando materiais ou concedendo desconto especiais em seus produtos. Igualmente, a Escola de Samba Vai-Vai, reduto de sambistas paulistanos, contribui participando das festividades com muito samba (Folha de S. Paulo, 03/08/1997; Site A, 1996; Coimbra, 1987).

A festa ainda tem atrativos como as danças e canções napolitanas, a apresentação de grupos folclóricos e a "linha de produção" da fogaça, com mais de cem pessoas sob o comando de "seu" Vicenzo e dona Neuza. A preparação dos alimentos insere-se em parte na estrutura de economia tradicional, pois apresenta aspectos artesanais de mutirão e o falatório que descontrai e ameniza o esforço dos que trabalham. Também é comum a participação de famílias cujos membros trabalham em conjunto e não isoladamente. Entretanto, a festa cresceu de tal forma que se tornou impossível preservar todas as características artesanais do preparo dos alimentos. Foi preciso confiar a uma padaria do bairro a preparação da massa da fogaça. O macarrão também é industrializado, embora os molhos continuem a ser preparados pelas "mammas" (Coimbra, 1987). Outra tradição da festa é o sorteio de 
um queijo provolone com dois metros de comprimento e cerca de cem quilos entre os que freqüentam as barracas.

A parte profana da festa desenvolve-se paralelamente às atividades religiosas, entre elas a tradicional Novena da Achiropita, que acontece durante a semana, animada por corais especialmente convidados.

Lotada de fiéis, a igreja recebe intensa visitação à Santa, paralelamente às orações e bênçãos. A procissão em louvor à Nossa Senhora Achiropita pelas ruas do bairro (com a costumeira homenagem dos alunos da Escola Maria José, que confeccionam o tapete de flores da rua Manoel Dutra) é minuciosamente preparada, do mesmo modo que a Festa da Apoteose, no encerramento, com atrações especiais na rua e na cantina da Madonna. No tapete, feito de flores, tampinhas de garrafa e serragem, as inscrições elaboradas pelos jovens demonstram suas preocupações. Em 1997, uma delas lembrava o sociólogo Betinho, outra recomendava o uso de camisinha no combate à AIDS, outra exaltava o futebol.

Observam-se, nas janelas de alguns prédios, toalhas e lençóis estendidos para saudar a santa, hábito tradicional. Este costume servia, inclusive, para sublinhar as distinções entre ricos e pobres do bairro. Atualmente, tal prática incorporou-se aos símbolos da festa, depois de reconquistada pela ação dos moradores, que a haviam abandonado durante alguns anos em razão do desânimo gerado pela intervenção excessiva da Igreja, ao ditar regras e "organizar" a seu modo o festejo.

Essa era uma hora também de mostrar o potencial econômico. A filha do fulano ia com aquela seda; o do pobre ia com cetim, sei lá. E a segunda coisa para mostrar o potencial financeiro da pessoa, que eram os quiaquiarones, eram as colchas na janela. Toda casa punha uma colcha na janela. Você passava na casa dos Biondi, dos Pórrio, dos Tenaglia, por exemplo, era aquela colcha de seda. Passava na casa do meu avô, era colcha vagabunda. Eles faziam questão de mostrar, pela colcha, quem cada um era. E era uma homenagem que se prestava à santa. Em 1982 tinha morrido isso. Então, a comissão da União do Bexiga (era eu e o Walter Taverna), antes da procissão, fizemos uns cartazes e fomos entregando de casa em casa, de prédio em prédio onde ela ia passar, pedindo para todo mundo voltar a colocar colcha na janela. Foi a coisa mais bonita que já vi! Uns $60 \%$ das janelas, dos prédios, tinham uma toalha (jogavam papel picado), tinha até toalha de rosto, nos cortiços etc. Mas tinha. Tem uma foto lá no museu que mostra a colcha e o altar da família Scarlatto. Eles colocavam na janela. Até hoje eles fazem. (Seu Armandinho do Bexiga, apud Moreno, 1996)

A retomada da organização da festa, segundo Coimbra (1987), foi uma conquista dos moradores do bairro, que conseguiram negociar seus interesses e os da igreja. São eles, inclusive, que decidem, atualmente, de que modo será aplicado o lucro angariado com ela.

Como acontece na Festa do Divino, a da Achiropita, no princípio, também era promovida por um festeiro anual, escolhido por sorteio entre os 
candidatos ou por promessa. Hoje, esta figura se tornou coletiva, uma vez que toda a comunidade se responsabiliza pela festa.

\begin{abstract}
Alguns informantes contam que, para angariar prendas, a comissão de festeiros contratava uma banda, que percorria as ruas do bairro com um estandarte e a imagem da santa, indo até o largo de Piques. Os festeiros acompanhavam a banda, arrecadando bebidas, cabritos, leitões e perus, que depois de assados seriam leiloados. Realizavam-se muitos leilões, mas não se montavam barracas de comida. (Coimbra, 1987, p. 71)
\end{abstract}

Os comerciantes donos de armazéns ofertaram as grandes prendas, que foram levadas das casas numa carroça. Para arrecadar fundos para a construção da igreja, por exemplo, a comissão organizadora angariou dinheiro, objetos de ouro e mesmo utensílios de uso doméstico (como panelas) oferecidos à Santa por seus devotos. Ainda hoje as doações e prendas provêm, na maior parte, de moradores do bairro e comerciantes.

"É tradição de quase todas as padarias do bairro oferecerem pães italianos. (...) O proprietário de uma churrascaria do bairro dá toda a carne e lingüiça necessários ao consumo da barraca de churrasco; uma família de origem italiana, residente no bairro, doa as flores para enfeitar o andor. Para angariar fundos, meses antes da festa a igreja lança a campanha de mensalistas. (...) Para contribuir as pessoas [que têm conta bancária] vão ao banco e assinam uma carta autorizando a fazer um desconto mensal de uma determinada quantia (...) Muitas empresas também colaboram, fornecendo, por exemplo, aventais, guardanapos, copos ou o programa da festa, sempre com o símbolo (marca) da empresa doadora" (Coimbra, 1987, p. 134).

A comida também foi introduzida tardiamente na festa, que até então seguia o estilo de quermesse. A descoberta do interesse do público em geral pela comida das mammas resultou em sua incorporação, que se tornou tradição.

Os organizadores não cansam de repetir que o sucesso da festa se mede pelo crescente público que prestigia o evento, fruto do trabalho voluntário de seiscentos membros da comunidade do Bexiga.

A arrecadação obtida com a festa é revertida integralmente para as obras assistenciais dirigidas pelos devotos da santa. Entre os projetos desenvolvidos estão o Centro Educacional Dom Orione (CEDO) e a Casa Dom Orione, que recebem e abrigam crianças e adultos carentes. Desde 1989, quando foi criado, o CEDO abriga 320 crianças carentes com idade entre 7 e 15 anos. Elas recebem aulas de reforço escolar, treinamento profissional e participam de atividades culturais. O CEDO surgiu a partir da constatação e preocupação com a exploração dos menores carentes do bairro, moradores de cortiços, por pessoas de outras regiões da cidade. Assim, o primeiro objetivo do CEDO foi orientá-las para a vida profissional. "Quando cheguei à paróquia, era comum ver crianças na rua com pedras nas mãos para roubar toca-fitas de carros (...) Precisávamos fazer algo para que as pessoas parassem de usar as crianças", diz padre Toninho. 
Em outubro de 1996, as Obras Assistenciais Nossa Senhora da Achiropita e a Petrobrás assinaram um convênio para que os adolescentes apoiados pela comunidade ao completarem 14 anos pudessem estagiar por dois anos na empresa. Por meio do convênio, os alunos do CEDO entram em contato com o ambiente de trabalho e conhecem como funciona uma grande empresa, aprendem métodos de trabalho, computação e capacitam-se para o mercado.

A Casa Dom Orioni também acolhe mulheres e homens de rua, aos quais oferece roupas, alimentação e local para tomar banho. Atualmente, recebe diariamente 120 pessoas, todas cadastradas pela entidade. A partir da experiência de organização da festa, também foi criado o "Grupo de Terceira Idade", com atividades de lazer e integração social. Além disso, a igreja presta serviços de assistência médica, psicológica, odontológica e jurídica para as pessoas carentes do bairro.

Carmem Cinira Macedo observa que:

Fazer festa é (...) também uma forma de prestígio e prover uma relativa redistribuição de bens. As festas contribuem para renovar os vínculos de sociabilidade tanto quanto definem um campo de relativa competição social. (Macedo, 1985, p. 45)

À medida que cresce, insuflada pela mídia, a festa incrementa igualmente o número de obras sociais, ajudando a suprir a ineficiência da ação social do Estado. O crescimento da festa, ao mesmo tempo, demanda cada vez mais a colaboração de empresas e entidades que, ao promoverem eventos paralelos em homenagem à Nossa Senhora Achiropita, acabam por interferir nela, nem sempre de modo bem-vindo pelos organizadores e voluntários. Walter, assíduo frequientador das festas da Achiropita há pelo menos 10 anos, diz que a publicidade excessiva descaracterizou-a. Mesmo a comida, afirma, perdeu a qualidade, dado o ritmo de produção em que é preparada com o intuito de servir a um público.

As pessoas que participam de sua produção estabelecem ainda uma espécie de "carreira" concomitante na política da festa e da igreja, como é o caso de Dona Daisy, sobre a qual Maria Fernanda Vomero, jornalista que "milita" na festa da Achiropita, diz:

Começou como diretora social da Festa d'Achiropita e membro do Encontro de Casais com Cristo (ECC). Já passou também pela pastoral do batismo. Hoje, é catequista, Ministra da Eucaristia e Coordenadora do Apostolado da Oração. Não pretende abandonar o bairro e, muito menos, a paróquia. (Maria Fernanda Vomero, Site A, 1997, grifos meus)

A participação nesse trabalho coletivo visa construir uma sociedade mais justa. Para levá-lo a cabo, é preciso aprender a lidar com vontades e interesses divergentes, diferentes estilos e possibilidades de ação, verbas, conceitos religiosos, mazelas do cotidiano, entraves burocráticos, legisla- 
ções municipais, estaduais e federais, o que implica um aprendizado de cidadania, mesmo que incipiente. O exemplo de Rita de Cássia Melita, citado por Vomero no site da Achiropita, esclarece os tipos de compensação e aprendizado possíveis de extrair da participação na festa:

Rita já esticou fogazza, coordenou a barraca de doces e a da fogazza na rua, vendeu souvenir, foi responsável pelo almoxarifado e por um setor da cantina. Quando começou a participar da Festa, o prédio das Obras Sociais, que hoje abriga o Centro Educacional Dom Orione, não existia ainda. 'Mas era um sonho das pessoas que trabalhavam aqui. E eu senti que comecei a fazer parte deste sonho', recorda-se, com carinho. 'Cada vez que você estica uma fogazza, joga farinha e frita, que você oferece um doce ou um prato de macarrão, seu ato vai concretizando esse sonho conjunto'. (Site A, 1997)

A realização da festa religiosa, baseada na fé aos santos, serve de pretexto e mote para a redistribuição de recursos aos mais pobres, gera empregos no setor turístico em Caruaru, Pernambuco, viabiliza a construção de creche e escola para crianças carentes no bairro do Bexiga, em São Paulo. A festa constitui, pois, um instrumento capaz de operar mudanças sociais. Ao realizá-la, a comunidade aprende a planejar e organizar eventos de grande porte, a definir, atribuir e realizar tarefas, a pressionar o Estado, a demandar investimentos de empresários, a negociar com a administração eclesiástica. Seus participantes adquirem consciência de sua importância e percebem que são capazes de realizar grandes eventos e projetos sociais. A festa, desse modo, não pode ser vista apenas como manifestação religiosa. Ela também estabelece uma "parceria" entre homens e deuses na luta por uma vida mais digna. É ritual, divertimento e ação social simultaneamente. Reaviva velhas tradições, reforça laços de origem e de sociabilidade, dá ensejo a anseios e projetos coletivos. Dona Josefina, uma senhora de 80 anos que sempre participou da festa da Achiropita, disse, sobre os bons resultados da festa: "É tudo milagre da Achiropita. Feito com as nossas mãos, que são as únicas que ela tem pra usar aqui. Mas é tudo milagre dela".

\section{Referências}

ALVES, Luís Antônio. Pirenópolis: festa do Divino. Cultura, s/local, v. 1, n. 2, abr.-jun 1971.

ALVES, Isidoro M. da Silva. O carnaval devoto: um estudo sobre a festa de Nazaré, em Belém. Petrópolis: Vozes, 1980.

AMARAL, Rita. Festa "à brasileira" - sentidos do festejar no país que "não é sério". São Paulo: EbooksBrasil.com. E-Book, 2001. 2002 .

Xirê! - o modo de crer e de viver do candomblé. Rio de Janeiro: Educ/Editora Pallas,

AMARAL, Amadeu. Tradições populares. São Paulo: Hucitec, 1976.

AZEVEDO, Thales de. Folclore e Ciências Sociais. In: Ensaio de Antropologia, Salvador: Universidade da Bahia, 1959.

BRANDÃO, Carlos R. O divino, o santo e a senhora. Rio de Janeiro: Campanha de Defesa do Folclore Brasileiro (Funarte), 1973. 
. A Cultura na rua. Campinas: Papirus Editores, 1989.

BRANDÃO, Théo. Folguedos natalinos (Bumba-meu-boi). Alagoas: Museu Théo Brandão/Ufal, 1976.

CALDEIRA, Tereza Pires. A política dos outros. São Paulo: Brasiliense, 1984.

CASCUDO, Luís da Câmara. Dicionário do folclore brasileiro. (2 v.), Rio de Janeiro: Edições de Ouro, 1989.

COIMBRA, Maria C. C. Nossa Senhora Achiropita no Bexiga: uma festa religiosa do catolicismo popular na cidade São Paulo. Mestrado em Antropologia Social (Dissertação). USP, 1987.

DEL PRIORE, Mary. Festas e utopias no Brasil colonial. São Paulo: Brasiliense, 1984.

DIAS, Maria Odila Leite da Silva. Quotidiano e poder em São Paulo no século XIX. São Paulo: Brasiliense, 1984.

EWBANK, Thomas. Vida no Brasil. São Paulo: Edusp/Itatiaia, 1976.

FERRETTI, Sérgio et al. Tambor de crioula: ritual e espetáculo. São Luís: Secma/Comissão Maranhense de Folclore/Litograph, 1995.

MACEDO, Carmem.Cinira. A reprodução da desigualdade. São Paulo: Vértice, 1985.

MORAIS FILHO, Melo. Festas e tradições populares no Brasil. São Paulo: Edusp/Itatiaia, 1979.

MORENO, Júlio. Memórias de Armandinho do Bixiga. São Paulo: Senac, 1996.

RUGENDAS, Johann Moritz. Viagem pitoresca através do Brasil. São Paulo: Martins Fontes/Edusp, 1972.

ZALUAR, Alba M. Os homens de Deus: um estudo dos santos e das festas no catolicismo popular. Rio de Janeiro: Zahar, 1983.

\section{Webgrafia}

N. Sra. da Achiropita - (http://www.bixiga.com.br)

São João de Caruaru - (http://www.softex.com.br)

São João de Caruaru - (http://www.cyberland.recife.softex.com.br) 